\title{
Penentuan Aktivitas Antioksidan Berdasarkan Nilai IC 50 Ekstrak Metanol dan Fraksi Hasil Partisinya pada Kulit Biji Pinang Yaki (Areca vestiaria Giseke)
}

\author{
Filberta* $^{*}$, Harry S. J. Koleangana, Max R. J. Runtuwenea, Vanda S. Kamua \\ aJurusan Kimia, FMIPA, Unsrat, Manado
}

\begin{tabular}{|c|c|}
\hline KATA KUNCI & A B S T R A K \\
\hline $\begin{array}{l}\text { Areca vestiaria Giseke } \\
\text { Antioksidan } \\
\text { IC }_{50}\end{array}$ & $\begin{array}{l}\text { Tujuan dari penelitian ini adalah untuk menentukan nilai IC } 50 \text { ekstrak } \\
\text { metanol dan hasil partisinya dari ekstrak Areca vestiaria Giseke. } \\
\text { Penelitian dimulai dengan proses maserasi menggunakan pelarut } \\
\text { metanol, kemudian dievaporasi pada suhu } 40^{\circ} \mathrm{C} \text { dan menghasilkan } 27,3 \mathrm{~g} \\
\text { ekstrak pekat dari } 330,2 \mathrm{~g} \text { sampel. Selanjutnya, ekstrak metanol diuji } \\
\text { aktivitas antioksidannya dan diperoleh nilai } \mathrm{C}_{50} \text { sebesar } 8,3 \text { ppm.. Ekstrak } \\
\text { kemudian dipartisi dengan pelarut n-heksana, etil asetat dan air dan } \\
\text { dievaporasi. Seluruh fraksi kemudian diuji aktivitas antioksidannya dan } \\
\text { fraksi etil asetat menunjukkan aktivitas antioksidan yang paling baik } \\
\text { dengan nilai IC } \text { S }_{50} \text { sebesar } 10,9 \text { ppm. }\end{array}$ \\
\hline K E YWOR D S & A B S T R A C T \\
\hline $\begin{array}{l}\text { Areca vestiaria Giseke } \\
\text { Antioxidant } \\
\text { IC }_{50}\end{array}$ & $\begin{array}{l}\text { The purposes of this research were to determine the } \mathrm{IC}_{50} \text { values from } \\
\text { methanol extract and its extract partition of extract Areca vestiaria Giseke. } \\
\text { The research was started with maceration process using methanol as a } \\
\text { solvent, then evaporated at } 40^{\circ} \mathrm{C} \text { which produce } 27,3 \mathrm{~g} \text { extract from } 330,2 \\
\mathrm{~g} \text { sample. After that, methanol extract was tested its antioxidant activity } \\
\text { and the result of } \mathrm{I}_{50} \text { values was } 8,3 \mathrm{ppm} \text {. And then, the extract was } \\
\text { partitioned with n-hexane, ethyl acetate and water and evaporated. All of } \\
\text { the fraction was then tested its antioxidant activity. Ethyl acetate fraction } \\
\text { showed the best antioxidant activity with } \mathrm{IC}_{50} \text { values of } 10,9 \mathrm{ppm} \text {. }\end{array}$ \\
\hline
\end{tabular}

TERSEDIA ONLINE

22 Oktober 2014

\section{Pendahuluan}

Pinang yaki atau pinang merah merupakan jenis palem liar yang bisa dijumpai di daerah tanah vulkanik. Pinang yaki (Areca vestiaria) merupakan jenis palem endemik Sulawesi yang memiliki karakteristik yang unik dan merupakan salah satu komponen penting hutan hujan tropis (Simbala, 2007). Di Sulawesi Utara, tanaman ini dapat dijumpai di kawasan Taman Nasional Bogani Nani Wartabone. Selain di Taman Nasional Bogani Nani Wartabone, pinang yaki juga tumbuh di cagar alam Gunung Ambang Kabupaten Bolaang Mongondow, cagar alam Gunung Tangkoko Dua Saudara, lereng Gunung Soputan, Gunung Mahawu Kabupaten Minahasa. Masyarakat di Bolaang Mongondow yang tinggal di kawasan Taman Nasional Bogani Nani Wartabone sering memanfaatkan pinang yaki ini sebagai obat untuk penyakit diabetes, dan juga sebagai obat kontrasepsi. Selain itu, pinang yaki juga dipakai oleh masyarakat sebagai obat cacing pada hewan ternak seperti kambing dan sapi (Simbala, 2007; Simbala and Tallei, 2010).

Buah pinang yaki memiliki kandungan senyawa metabolit sekunder seperti alkaloid, flavonoid, triterpenoid, steroid, dan tanin yang memiliki efek sebagai antikanker, antitumor, antibakteri, dan juga sebagai antifertilisasi (Simbala, 2007; Runtuwene dan Paendong, 2011). Efek yang ditimbulkan dari pinang yaki ini diduga karena adanya kandungan antioksidan. Antioksidan merupakan zat penangkal radikal bebas yang memiliki peranan penting dalam menghambat proses oksidasi lipida. Antioksidan juga sangat bermanfaat dalam pencegahan timbulnya berbagai 
penyakit. Peranan antioksidan sangat penting dalam menetralkan dan menghancurkan radikal bebas yang dapat menyebabkan kerusakan sel dan juga merusak biomolekul, seperti DNA, protein, dan lipoprotein di dalam tubuh yang akhirnya dapat memicu terjadinya penyakit degeneratif seperti kanker, jantung, artritis, katarak, diabetes dan hati. Penyakit degeneratif ini disebabkan karena antioksidan yang ada didalam tubuh tidak mampu menetralisir peningkatan konsentrasi radikal bebas. Untuk menghindari hal tersebut, dibutuhkan antioksidan tambahan dari luar atau antioksidan eksogen, seperti vitamin E, vitamin C, maupun berbagai jenis sayuran dan buah-buahan (Soeksmanto et al., 2007; Simbala and Tallei, 2010).

Manfaat yang luar biasa dari pinang yaki ini menyebabkan banyaknya orang yang tertarik untuk melakukan penelitian mengenai pinang yaki ini. Simbala (2007) mengidentifikasi awal senyawa metabolit sekunder yang ada pada buah pinang yaki. Selanjutnya, Lisa (2011) menguji toksisitas dan mengidentifikasi senyawa kimia yang ada pada ekstrak etanol dan petroleum eter buah (kulit dan biji) pinang yaki dengan menggunakan GC-MS. Runtuwene dan Paendong (2011) juga melakukan kajian fitokimia dan toksisitas pada ekstrak metanol daun pinang yaki. Selanjutnya, Aralaha (2011) menguji aktivitas antioksidan pada biji buah pinang yaki yang dihidrolisis dan tanpa hidrolisis. Ismail et al. (2012) juga melakukan penentuan total fenolik dan pengujian aktivitas antioksidan pada biji dan kulit buah pinang yaki dengan ekstrak etanol, serta Mokoginta et al. (2013) yang melakukan penelitian tentang pengaruh metode ekstraksi terhadap aktivitas penangkal radikal bebas ekstrak metanol kulit biji pinang yaki. Walaupun sudah dilakukan penelitian tentang aktivitas antioksidan pada pinang yaki dengan metode ekstraksi maserasi dan terbukti bahwa pada pinang yaki memiliki aktivitas antioksidan yang tinggi pada konsentrasi $50 \mathrm{mg} / \mathrm{L}(74,61 \%)$ dan $100 \mathrm{mg} / \mathrm{L}$ $(81,32 \%)$, namun belum diketahui nilai $I_{50}$ dari ekstrak dan hasil partisinya pada pinang yaki tersebut sehingga menimbulkan pemikiran bahwa perlu dilakukan pengujian aktivitas antioksidan untuk mencari nilai $\mathrm{IC}_{50}$ pada ekstrak dan hasil partisi kulit biji pinang yaki tersebut.

Penelitian ini bertujuan untuk menentukan nilai $\mathrm{IC}_{50}$ ekstrak metanol dan hasil partisinya dari ekstrak Areca vestiaria Giseke.

\section{Metode}

\subsection{Material}

Peralatan yang digunakan dalam penelitian ini adalah oven, neraca analitik, Aluminium foil, alat penggiling, ayakan 65 mesh, desikator, labu pemisah, pipa kapiler, plat tetes, pemanas, satu set stirrer, satu set alat vacum rotatory evaporator, spektrometer UVVis, botol vial, mikropipet Eppendorf Research 1000 $\mu \mathrm{L}$, dan alat- alat gelas dengan kualitas pyrex.

Bahan baku yang digunakan dalam penelitian ini adalah kulit biji buah pinang yaki yang diperoleh dari gunung Mahawu kabupaten Minahasa. Bahan kimia yang digunakan dalam penelitian ini adalah kertas saring, akuades, dan bahan kimia berkualifikasi teknis yang didestilasi kembali, seperti: metanol, n-heksana, etil asetat, etanol, serta bahan kimia lainnya seperti: besi(III) klorida, asam klorida, asam sulfat, natrium hidroksida, reagen Dragendorff, reagen Wagner, asam asetat anhidrat, dietil eter, serbuk magnesium, 1,1-difenil2-pikrilhidrazil (DPPH) yang diperoleh dari MERCK.

\subsection{Prosedur Penelitian.}

Sampel kulit biji pinang yaki yang akan diuji aktivitas antioksidannya dipreparasi terlebih dahulu sebelum diekstraksi. Ektrak dibuat dengan cara maserasi menggunakan pelarut metanol sebanyak $1500 \mathrm{~mL}$ selama 24 jam. Setelah 24 jam, sampel disaring dan filtrat yang diperoleh ditampung. Sementara itu, residu hasil penyaringan diekstraksi lagi sebanyak dua kali seperti cara sebelumnya. Filtrat yang diperoleh dievaporasi menggunakan vacumrotatory evaporator pada suhu $40^{\circ} \mathrm{C}$ sampai diperoleh ekstrak pekat. Ekstrak pekat yang diperoleh kemudian diuji aktivitas antioksidannya untuk ditentukan nilai IC5onya. Ekstrak metanol kemudian dipartisi dengan n-heksana, etil asetat, dan air. Masing-masing fraksi diuji aktifitas antioksidan menggunakan metode DPPH dan ditentukan IC50.

\section{Hasil dan Pembahasan}

Pengujian aktivitas antioksidan dilakukan untuk mengetahui nilai $\mathrm{IC}_{50}$ dari sampel. Pengujian dilakukan terhadap ekstrak metanol sampel dan fraksi hasil partisi dan dilakukan dengan sistem duplo. Dari hasil pengujian, ekstrak metanol memiliki nilai $\mathrm{IC}_{50}$ sebesar 8,3 ppm. Nilai $I_{50}$ dari ekstrak metanol tergolong memiliki aktivitas antioksidan yang baik. Pengujian aktivitas antioksidan dari ekstrak metanol sampel dapat di lihat pada Tabel 1.

Tabel 1. Pengujian Antioksidan Ekstrak Metanol Areca vestiaria Giseke

\begin{tabular}{cccccc}
\hline $\mathbf{C}(\mathrm{ppm})$ & A1 & \% inhibisi 1 & C (ppm) & A2 & \% inhibisi 2 \\
\hline $\mathbf{0}$ & 0,788 & & 0 & 0,896 & \\
$\mathbf{2}$ & 0,714 & 9,39086294 & 2 & 0,716 & 20,08928571 \\
$\mathbf{4}$ & 0,597 & 24,2385787 & 4 & 0,613 & 31,58482143 \\
$\mathbf{8}$ & 0,32 & 59,3908629 & 8 & 0,412 & 54,01785714 \\
$\mathbf{1 6}$ & 0,133 & 83,1218274 & 16 & 0,13 & 85,49107143 \\
\hline
\end{tabular}


Berdasarkan Tabel 1, maka dapat diperoleh grafik yang dapat dilihat pada Gambar 1 .
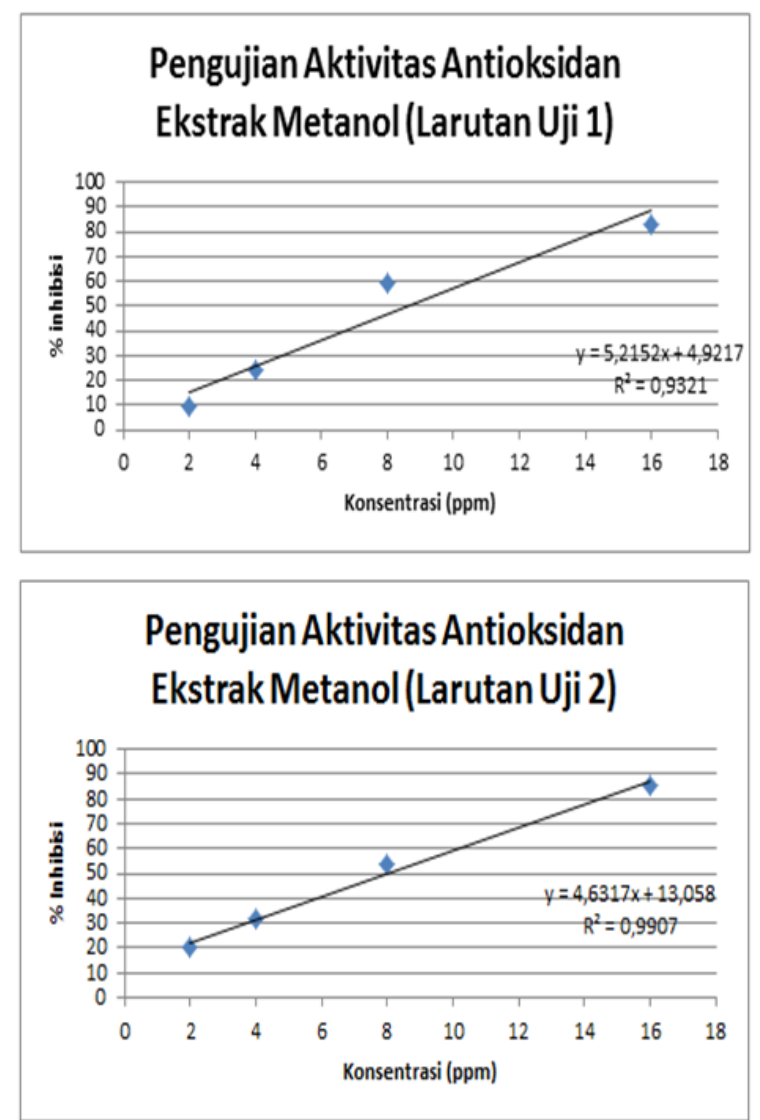

Gambar 1. Pengujian aktivitas antioksidan ekstrak metanol
Berdasarkan Gambar 1, diperoleh nilai y = $5,2152 x+4,9217$ untuk larutan uji 1 dan nilai $y=$ $4,6317 x+13,058$ untuk larutan uji 2. Berdasarkan nilai y pada pengujian aktivitas antioksidan ekstrak metanol Areca vestiaria Giseke, maka dapat diperoleh nilai $\mathrm{IC}_{50}$ dengan mengganti nilai y dengan angka 50 . Perhitungan nilai $\mathrm{IC}_{50}$ dijabarkan sebagai berikut:

$$
\begin{aligned}
& \text { Larutan Uji 1: } \\
& \begin{array}{l}
y=5,2152 x+4,9217 \\
50=5,2152 x+4,9217 \\
x=\frac{50-4,9217}{5,2152}=8,6
\end{array}
\end{aligned}
$$

Larutan Uji 2:

$$
\begin{aligned}
y=4,6317 x & +13,058 \\
50=4,6317 x & +13,058 \\
x & =\frac{50-13,058}{4,6317}=8,0
\end{aligned}
$$

Berdasarkan perhitungan nilai $\mathrm{IC}_{50}$ dari larutan uji 1 dan larutan uji 2 dari ekstrak metanol Areca vestiaria Giseke, maka diperoleh nilai $\mathrm{IC}_{50}$ sebesar 8,3 ppm. Nilai $\mathrm{IC}_{50}$ ekstrak metanol sampel diperoleh dari rata-rata $\mathrm{IC}_{50}$ larutan uji 1 dan larutan uji 2 dari ekstrak metanol Areca vestiaria Giseke.

Ekstrak metanol yang telah diuji aktivitas antioksidannya kemudian dipartisi dan hasil partisinya diuji aktivitas antioksidannya yang dapat dilihat pada Tabel 2 hingga Tabel 4 dan grafik pengujian aktivitas antioksidan fraksi hasil partisi sampel dapat dilihat pada Gambar 2 hingga Gambar 4.

Tabel 2. Pengujian Antioksidan Fraksi n-Heksana Areca vestiaria Giseke

\begin{tabular}{cccccc}
\hline $\mathbf{C}$ (ppm) & A1 & \% inhibisi 1 & $\mathbf{C}$ (ppm) & A2 & \% inhibisi 2 \\
\hline $\mathbf{0}$ & 0,67 & & 0 & 0,624 & \\
$\mathbf{2}$ & 0,61 & 8,95522388 & 2 & 0,615 & 1,442307692 \\
$\mathbf{4}$ & 0,582 & 13,1343284 & 4 & 0,584 & 6,41025641 \\
$\mathbf{8}$ & 0,565 & 15,6716418 & 8 & 0,569 & 8,814102564 \\
$\mathbf{1 6}$ & 0,54 & 19,4029851 & 16 & 0,541 & 13,30128205 \\
$\mathbf{3 2}$ & 0,492 & 26,5671642 & 32 & 0,503 & 19,39102564 \\
\hline
\end{tabular}
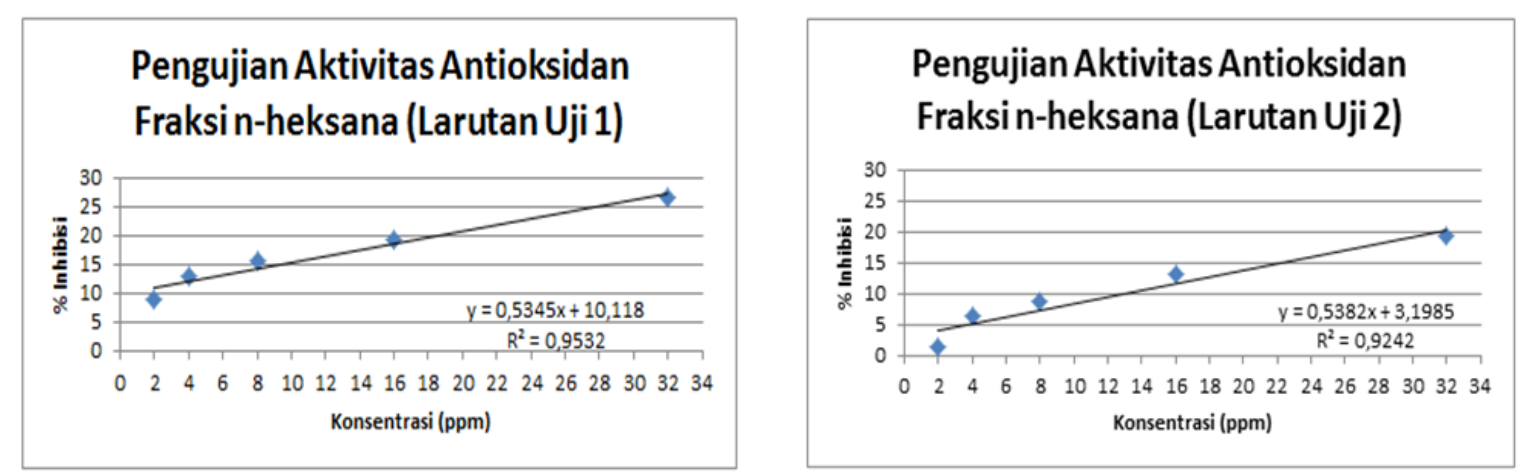

Gambar 2. Pengujian aktivitas antioksidan fraksi n-heksana 
Berdasarkan Gambar 2, diperoleh nilai $\mathrm{y}=$ $0,5345 x+10,118$ untuk larutan uji 1 dan nilai $y=$ $0,5382 x+3,1985$ untuk larutan uji 2. Berdasarkan nilai y pada pengujian aktivitas antioksidan fraksi nheksana Areca vestiaria Giseke, maka dapat diperoleh nilai $\mathrm{IC}_{50}$ dengan mengganti nilai y dengan angka 50. Perhitungan nilai $I C_{50}$ dijabarkan sebagai berikut:

$$
\begin{aligned}
& \text { Larutan Uji 1: } \\
& \begin{array}{l}
y=0,5345 x+10,118 \\
50=0,5345 x+10,118 \\
x=\frac{50-10,118}{0,5345}=74,6
\end{array}
\end{aligned}
$$

$$
\begin{aligned}
& \text { Larutan Uji } 2 \text { : } \\
& \begin{array}{l}
y=0,5382 x+3,1985 \\
50=0,5382 x+3,1985 \\
x=\frac{50-3,1985}{0,5382}=87,0
\end{array}
\end{aligned}
$$

Berdasarkan perhitungan nilai $\mathrm{IC}_{50}$ dari larutan uji 1 dan larutan uji 2 dari fraksi n-heksana Areca vestiaria Giseke, maka diperoleh nilai $\mathrm{IC}_{50}$ sebesar 80,80 ppm. Nilai $I_{50}$ ekstrak metanol sampel diperoleh dari rata-rata $\mathrm{IC}_{50}$ larutan uji 1 dan larutan uji 2 dari fraksi n-heksana Areca vestiaria Giseke.

Tabel 3. Pengujian Antioksidan Fraksi Etil Asetat Areca vestiaria Giseke

\begin{tabular}{ccrccr}
\hline $\mathbf{C}$ (ppm) & A1 & \% inhibisi 1 & C (ppm) & A2 & \% inhibisi 2 \\
\hline $\mathbf{0}$ & 0,834 & & 0 & 0,835 & \\
$\mathbf{0 , 5}$ & 0,818 & 1,91846 & 0,5 & 0,801 & 4,071856 \\
$\mathbf{1}$ & 0,777 & 6,83453 & 1 & 0,798 & 4,431137 \\
$\mathbf{2}$ & 0,746 & 10,5515 & 2 & 0,743 & 11,01796 \\
$\mathbf{4}$ & 0,666 & 20,1438 & 4 & 0,657 & 21,31736 \\
$\mathbf{8}$ & 0,527 & 36,8105 & 8 & 0,535 & 35,92814 \\
\hline
\end{tabular}
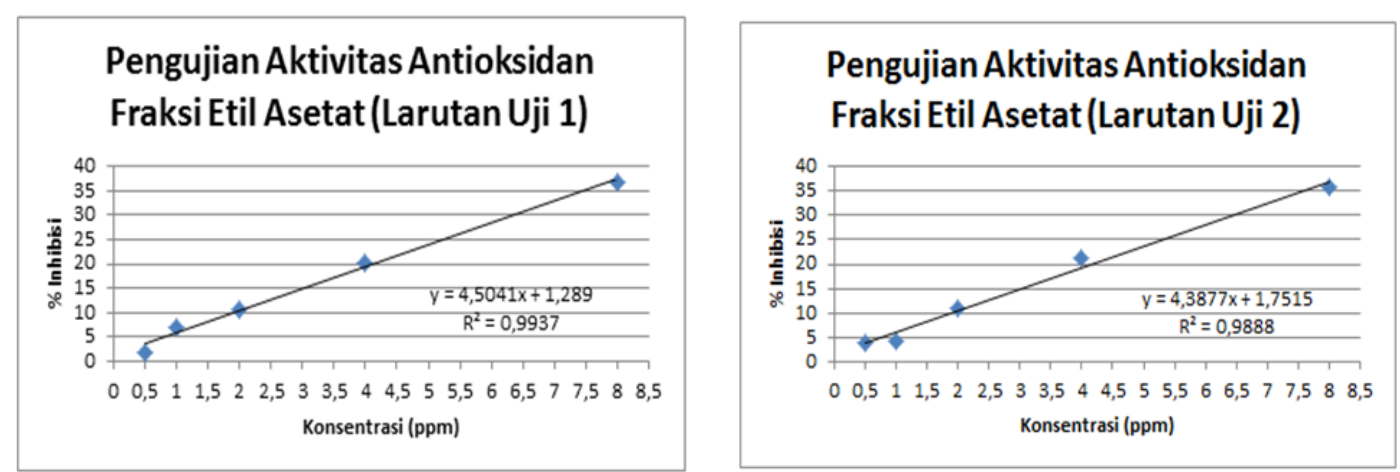

Gambar 3. Grafik Pengujian Aktivitas Antioksidan Fraksi Etil Asetat Areca vestiaria Giseke

Berdasarkan Gambar 3, diperoleh nilai $\mathrm{y}=$ $4,5041 x+1,289$ untuk larutan uji 1 dan nilai $y=$ $4,3877 x+1,7515$ untuk larutan uji 2. Berdasarkan nilai y pada pengujian aktivitas antioksidan fraksi etil asetat Areca vestiaria Giseke, maka dapat diperoleh nilai $\mathrm{IC}_{50}$ dengan mengganti nilai y dengan angka 50. Perhitungan nilai $\mathbf{I C}_{50}$ dijabarkan sebagai berikut:

$$
\begin{aligned}
& \text { Larutan Uji 1: } \\
& \begin{array}{l}
y=4,5041 x+1,289 \\
50=4,5041 x+1,289 \\
\qquad x=\frac{50-1,289}{4,5041}=10,8
\end{array}
\end{aligned}
$$

Larutan Uji 2:

$$
\begin{aligned}
y=4,3877 x & +1,7515 \\
50=4,3877 x & +1,7515 \\
x & =\frac{50-1,7515}{4,3877}=11,0
\end{aligned}
$$

Berdasarkan perhitungan nilai $\mathrm{IC}_{50}$ dari larutan uji 1 dan larutan uji 2 dari fraksi n-heksana Areca vestiaria Giseke, maka diperoleh nilai $\mathrm{IC}_{50}$ sebesar $10,90 \mathrm{ppm}$. Nilai $I_{50}$ ekstrak metanol sampel diperoleh dari rata-rata $\mathrm{IC}_{50}$ larutan uji 1 dan Iarutan uji 2 dari fraksi etil asetat Areca vestiaria Giseke. 
Tabel 4. Pengujian Antioksidan Fraksi Air Areca vestiaria Giseke

\begin{tabular}{rrrrrr}
\hline $\mathbf{C}(\mathbf{p p m})$ & A1 & \% inhibisi 1 & $\mathbf{C}$ (ppm) & A2 & \% inhibisi 2 \\
\hline $\mathbf{0}$ & 0,835 & & 0 & 0,829 & \\
$\mathbf{1}$ & 0,803 & 3,83233 & 1 & 0,812 & 2,050663 \\
$\mathbf{2}$ & 0,778 & 6,82634 & 2 & 0,762 & 8,082026 \\
$\mathbf{4}$ & 0,713 & 14,6107 & 4 & 0,703 & 15,19903 \\
$\mathbf{8}$ & 0,568 & 31,9760 & 8 & 0,594 & 28,34740 \\
\hline
\end{tabular}
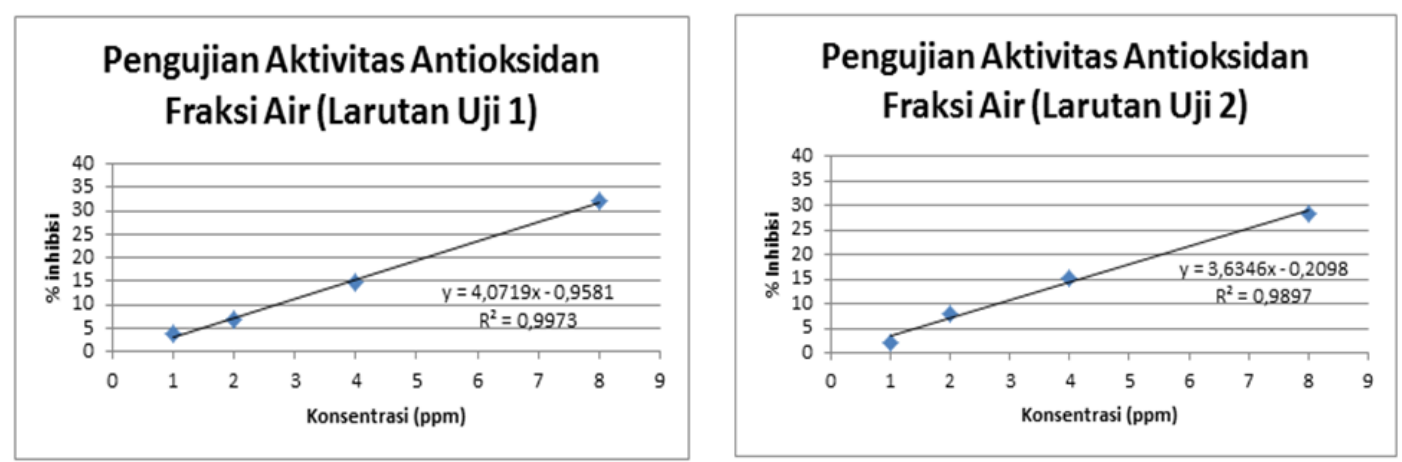

Gambar 4. Grafik Pengujian Aktivitas Antioksidan Fraksi Air Areca vestiaria Giseke iseke

Berdasarkan Gambar 4, diperoleh nilai y $=$ $4,0719 x+0,9581$ untuk larutan uji 1 dan nilai $y=$ $3,6346 x+0,2098$ untuk larutan uji 2. Berdasarkan nilai y pada pengujian aktivitas antioksidan fraksi air Areca vestiaria Giseke, maka dapat diperoleh nilai $\mathrm{IC}_{50}$ dengan mengganti nilai y dengan angka 50 . Perhitungan nilai I $\mathrm{C}_{50}$ dijabarkan sebagai berikut:

$$
\begin{aligned}
& \text { Larutan Uji 1: } \\
& \begin{array}{l}
y=4,0719 x+0,9581 \\
50=4,0719 x+0,9581 \\
x=\frac{50-0,9581}{4,0719}=12,0
\end{array}
\end{aligned}
$$

Larutan Uji 2:

$$
\begin{aligned}
y=3,6346 x & +0,2098 \\
50=3,6346 x & +0,2098 \\
x & =\frac{50-0,2098}{3,6346}=13,7
\end{aligned}
$$

Berdasarkan perhitungan nilai $\mathrm{IC}_{50}$ dari larutan uji 1 dan larutan uji 2 dari fraksi n-heksana Areca vestiaria Giseke, maka diperoleh nilai $\mathrm{IC}_{50}$ sebesar $12,85 \mathrm{ppm}$. Nilai IC 50 ekstrak metanol sampel diperoleh dari rata-rata $I_{50}$ larutan uji 1 dan larutan uji 2 dari fraksi air Areca vestiaria Giseke.

Berdasarkan pengujian aktivitas antioksidan dari fraksi hasil partisi, terlihat bahwa fraksi etil asetat memiliki aktivitas antioksidan yang paling baik dengan nilai IC 50 sebesar 10,09 ppm. Semakin rendah nilai $\mathrm{IC}_{50}$, maka akan semakin baik aktivitas antioksidan dari sampel hasil pengujiannya. Hasil pengujian dari aktivitas antioksidan berdasarkan nilai $\mathrm{IC}_{50}$ dapat disajikan secara sederhana dalam Tabel 5.
Tabel 5. Aktivitas Antioksidan Fraksi Hasil Partisi.

\begin{tabular}{cc}
\hline Fraksi & Nilai IC $_{50}(\mathrm{ppm})$ \\
\hline n-heksana & 80,80 \\
Etil Asetat & 10,90 \\
Air & 12,85 \\
\hline
\end{tabular}

Pengujian aktivitas antioksidan dari ekstrak metanol dan hasil partisinya menunjukkan bahwa sampel memiliki aktivitas penghambatan yang lebih baik pada ekstrak metanolnya daripada hasil partisinya. Hal ini disebabkan karena adanya beberapa senyawa aktif yang terdapat dalam ekstrak dapat bersinergi dalam menghambat radikal bebas, sehingga nilai $\mathrm{IC}_{50}$ dari ekstrak lebih baik dari fraksinya.

\section{Kesimpulan}

Ekstrak metanol Areca vestiaria Giseke memiliki aktivitas antioksidan yang lebih baik dari fraksi hasil partisinya. Aktivitas antioksidan dari ekstrak metanol Areca vestiaria Giseke memiliki nilai IC 50 sebesar 8,3 ppm. Berdasarkan fraksi hasil partisi dari ekstrak metanol Areca vestiaria Giseke, fraksi etil asetat memiliki aktivitas antioksidan yang lebih baik dari fraksi lainnya. Nilai IC $_{50}$ dari fraksi etil asetat sebesar $10,90 \mathrm{ppm}$ dan nilai $\mathrm{IC}_{50}$ dari fraksi n-heksana sebesar 80,80 ppm, serta nilai $I_{50}$ dari fraksi air sebesar 12,85 ppm. 


\section{Daftar Pustaka}

Aralaha, N. 2011. Uji Aktivitas Antioksidan pada Biji Buah Pinang Yaki yang Dihidrolisis dan Tanpa Hidrolisis [Skripsi]. FMIPA UNSRAT, Manado.

Ismail, J., M.R.J. Runtuwene, dan F. Fatimah. 2012. Penentuan Total Fenolik dan Pengujian Aktivitas Antioksidan pada Biji dan Kulit Buah Pinang Yaki dengan Ekstrak Etanol. Jurnal IImiah Sains. 2: 84-88.

Lisa, R. 2011. Uji Toksisitas dan Identifikasi Senyawa Kimia pada Ekstrak Etanol dan Petroleum Eter Buah (Kulit Dan Biji) Pinang Yaki dengan Menggunakan GC-MS [Skripsi]. FMIPA UNSRAT, Manado.

Mokoginta, E.P., M.R.J. Runtuwene, dan F. Wehantouw. 2013. Pengaruh Metode Ekstraksi Terhadap Aktivitas Penangkal Radikal Bebas Ekstrak Metanol Kulit Biji Pinang Yaki (Areca vestiaria Giseke). Pharmacon. 2: 109-113.
Runtuwene, M.R.J. dan J. Paendong. 2011. Kajian Fitokimia dan Toksisitas Ekstrak Metanol Daun Pinang Yaki Areca Vestiaria Giseke. Chemistry Progress. 4: 80-84.

Simbala, H.E.I. 2007. Keanekaragaman Floristik dan Pemanfaatannya Sebagai Tumbuhan Obat di Kawasan Konservasi II Taman Nasional Bogani Nani Wartabone (Kabupaten Bolaang Mongondow Sulawesi Utara) Provinsi Sulawesi Utara [Disertasi]. FMIPA IPB, Bogor.

Simbala, H.E.I. and T.E. Tallei.2010. Ethnobotanical, Proximate, and Phytochemical Studies Of Areca vestiaria Giseke (Pinang Yaki). International Conference on Medicinal Plants, Surabaya.

Soeksmanto, A., Y. Hapsari, dan P. Simanjuntak. 2007. Kandungan Antioksidan pada Beberapa Bagian Tanaman Mahkota Dewa, Phaleria macrocarpa (Scheff) Boerl. (Thymelaceae). Biodiversitas. 8: 92-95. 